\title{
Syntelencephaly associated with cystic cochleovestibular malformations
}

Figure 1 Syntelencephaly
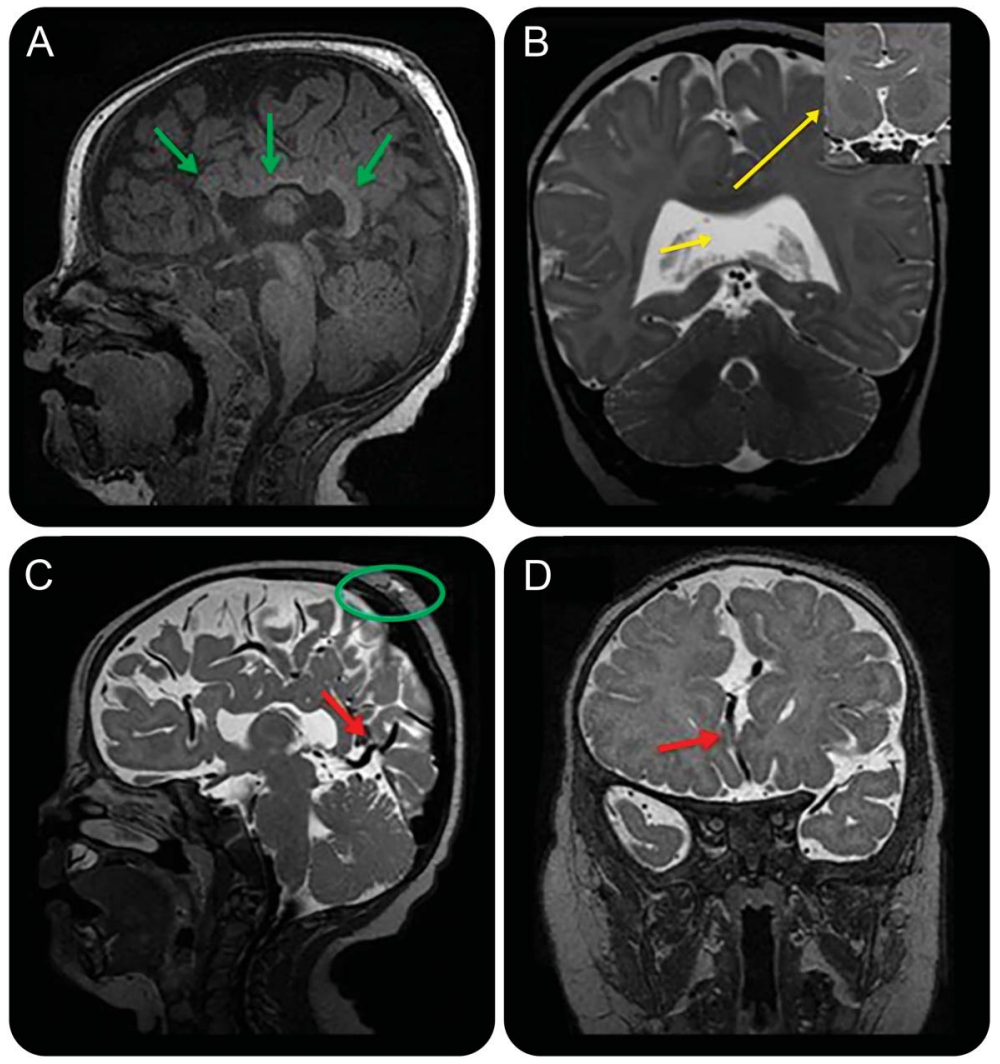

(A) Partial intermediate agenesis of corpus callosum is shown. (B) Failure of cleavage of the posterior frontal and anterior parietal regions with normal cortex bridging the midline and absent septum pellucidum. (C, D) Atretic parietal cephalocele, persistent falcine sinus, and azygous anterior cerebral artery.

A 3-month-old boy presented with bilateral profound hearing loss. Examination of ears was unremarkable. Brain MRI revealed syntelencephaly with associated other anomalies (figures 1 and 2).

Syntelencephaly or middle interhemispheric subtype of holoprosencephaly is characterized by abnormal midline connection of the posterior frontal and parietal lobes with normal separation of rostral forebrain. ${ }^{1,2}$ The coexistence of syntelencephaly and other anomalies such as cystic cochleovestibular malformation, persistent falcine sinus, and parietal encephalocele is unknown and raises the question of pathogenic association or coincidence among them.

Yakup Akyol, MD, Vinay Kandula, MD, Arabinda Choudhary, MD

From the Nemours/Alfred I. duPont Hospital for Children, Department of Medical Imaging, Wilmington, DE.

Author contributions: Yakup Akyol: corresponding author, saw cases, and searched literature. Vinay Kandula: author, saw cases, and searched literature. Arabinda Choudhary: author, saw cases, and searched literature.

Study funding: No targeted funding reported.

Disclosure: The authors report no disclosures relevant to the manuscript. Go to Neurology.org for full disclosures.

Correspondence to Dr. Akyol: akyolyakup@yahoo.com 

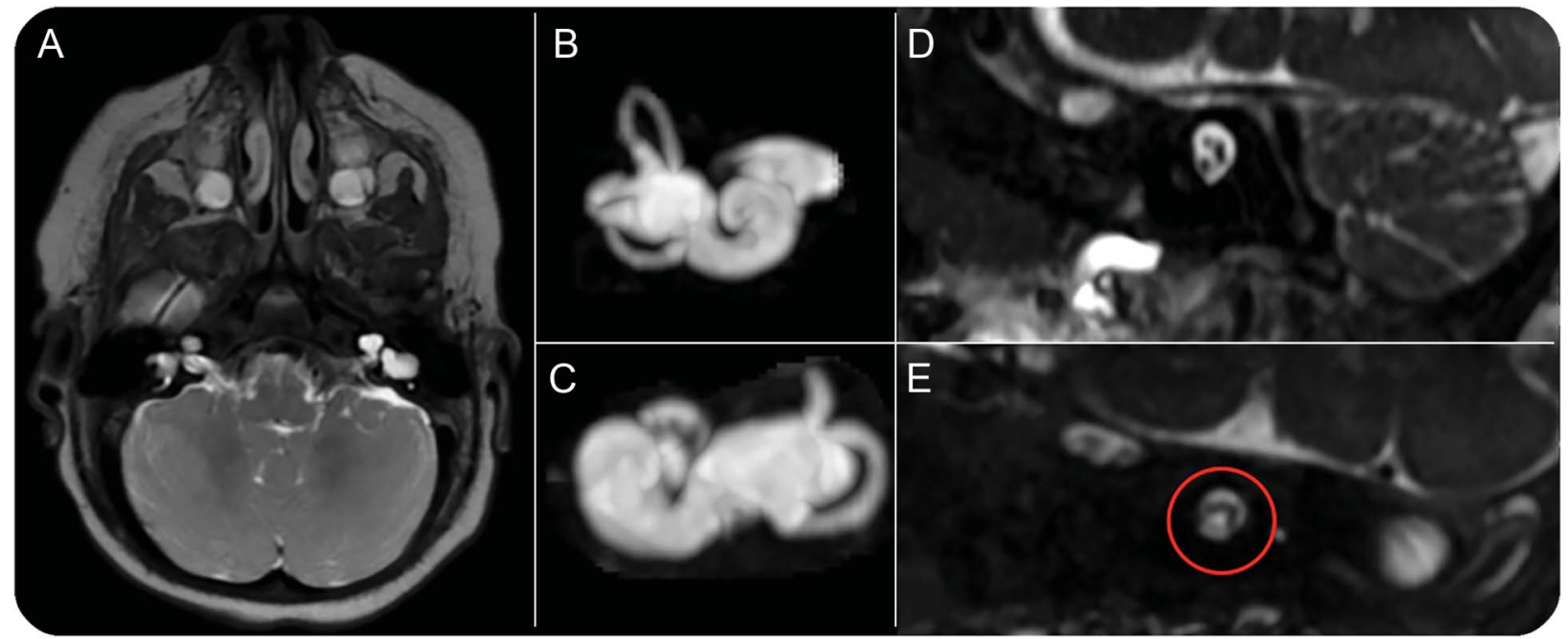

(A) Axial T2-weighted image shows incompletely partitioned bilateral cochleas with dysmorphic vestibules. (B, C) Three-dimensional reformatted images show absent left transverse semicircular canal and enlarged and dysplastic right transverse and left superior semicircular canals. Normal right (D) and absent left $(E$, circle) cochlear nerves.

1. Lewis AJ, Simon EM, Barkovich AJ, et al. Middle interhemispheric variant of holoprosencephaly: a distinct cliniconeuroradiologic subtype. Neurology 2002;59:1860-1865.

2. Picone O, Hirt R, Suarez B, et al. Prenatal diagnosis of a possible new middle interhemispheric variant of holoprosencephaly using sonographic and magnetic resonance imaging. Ultrasound Obstet Gynecol 2006;28:229-231.

\section{How Do YOU Compare? Access New Neurology Compensation and Productivity Report}

The AAN's 2015 Neurology Compensation and Productivity Report is now available. Based on data from more than 1,300 neurologists and neurology practice managers, this is the most recent and reliable information on the neurology profession.

The Neurology Compensation and Productivity Report is a powerful, versatile tool that can help you:

- Compare and customize your individual practice-related data with your colleagues at national and local levels

- Determine if you are being paid fairly relative to your peers

- Use the data in contracting with payers and demonstrating your value

- Discover fair market value based on your subspecialty, region, and practice type

- Create charts and graphs and download them right to your desktop

- Assess patient and practice management principals and implement efficiencies that ultimately can help improve the quality of patient care

Learn more at $A A N . c o m / v i e w / 2015$ NeuroReport. 


\section{Neurology}

\section{Syntelencephaly associated with cystic cochleovestibular malformations Yakup Akyol, Vinay Kandula and Arabinda Choudhary \\ Neurology 2016;86;198-199 \\ DOI 10.1212/WNL.0000000000002269}

\section{This information is current as of January 11, 2016}

Updated Information \& Services

References

Subspecialty Collections

Permissions \& Licensing

Reprints including high resolution figures, can be found at: http://n.neurology.org/content/86/2/198.full

This article cites 2 articles, 1 of which you can access for free at: http://n.neurology.org/content/86/2/198.full\#ref-list-1

This article, along with others on similar topics, appears in the following collection(s):

All Clinical Neurology

http://n.neurology.org/cgi/collection/all_clinical_neurology MRI

http://n.neurology.org/cgi/collection/mri

Information about reproducing this article in parts (figures,tables) or in its entirety can be found online at:

http://www.neurology.org/about/about_the_journal\#permissions

Information about ordering reprints can be found online:

http://n.neurology.org/subscribers/advertise

Neurology $®$ is the official journal of the American Academy of Neurology. Published continuously since 1951 , it is now a weekly with 48 issues per year. Copyright @ 2016 American Academy of Neurology. All rights reserved. Print ISSN: 0028-3878. Online ISSN: 1526-632X.

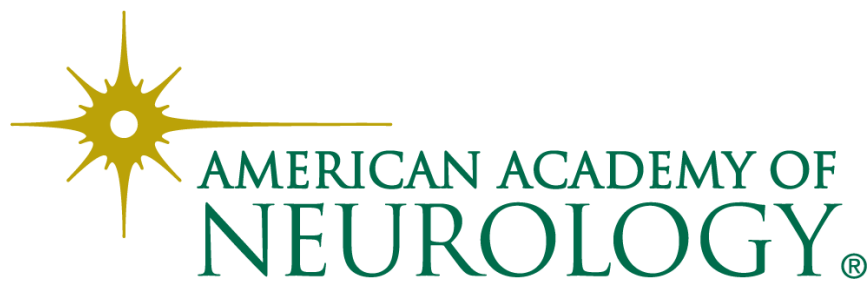

